\title{
CORRESPONDENCE
}

\section{THE OIL-FIELD BELT OF SOUTH-WEST IRAN AND IRAQ}

SiR,- Those who have worked in South-West Persia for the Anglo-Iranian Oil Company will have read with great interest the account by Dr. G. M. Lees and F. D. S. Richardson of the latest geological advances that have been made there. "Unconformity," as playing any considerable part in the variations of thickness of the Lower Fars, seems to have finally gone by the board, yet in the period 1915-1920, it was only with the greatest difficulty that field workers obtained from the authorities at home a grudging admission that large thrusts and great flow sheets existed at all.

Most of the movement has occured from north-east to southwest, namely away from the main Zagros ranges, but a few back thrusts of considerable extent are found, notably at Lali, which district was first explored and mapped in 1917 by the writer and W. R. A. Weatherhead. A well was at that date recommended not far from the line of strike of the gas escapes shown in the section (p. 245), and well back from the Lali back-thrust, which would probably have got the Asmari limestone, but this was across the River Karun (shown as a nick in the section), and it is this formidable barrier which has, as much as geological considerations, prevented the Company from drilling further to the north-east. It is possible that the limestone dips much less steeply to the north-east than is shown.

The authors believe that the movement of the Lower Fars and the rocks above it in the Jehangiri syncline was from southwest to north-east (p. 248), but it would have been better to have extended the section to show the interpretation of their theory as far as the main Zagros Ranges, which rise to over 5,000 feet only io miles or so to the north-east. It seems to the writer more likely that the movement was in the opposite direction, and that the wave-like rise and advance of these folds was the propelling force. (The frontispiece of my book on Earth Flexures is an illustration of the Asmari fold adjacent to the area in question.) It is difficult to reconcile the supposed north-easterly movement of the Jehangiri with that proved to be south-westerly of the Lower Fars at Masjid-i-Suleiman only 20 miles away along the strike. There is no evidence of 
such a pivotal movement. As I conceive it, the evidence points to the probability that the Jehangiri syncline has moved forward to the south-west for 6 or 7 miles, shearing off the Lower Fars from the top of the Asmari anticline, and slumping the material into the depression under Zeloi, to the south-west of which there is again a deep syncline. The steep and rigid southwest flank of the Jehangiri syncline formed a propelling wall. By this interpretation the north-easterly sheet above the Lali thrust plane (not shown in the section) becomes a shallow "slop-over" underthrust by the adjacent great syncline to the north-east.

As for the mechanics that produced these and similar movements throughout the region, we suggest that the Zagros Ranges have in the past advanced (and are even still advancing), in wave-like undulations, and that the Lower Fars rock sheets ride in front of them, over Asmari anticline and Bakhtiari syncline, like surf-boards in front of a nearly breaking sea. The advancing "surf-board" scarps of the Lower Fars can be observed to-day, and profoundly modify the drainage lines.

There is probably no district in the world where the geology is better exposed, and where at the same time geological and geophysical talent has been more lavishly expended. But, as in all the sciences, the greater the knowledge attained the less we seem to know.

Santa Elena,

H. G. BusK.

EcUADOR. 